Pakistan Journal of Nutrition 15 (9): 867-872, 2016

ISSN 1680-5194

(C) Asian Network for Scientific Information, 2016

\title{
Crude Nutrient and Mineral Composition of Asystasia gangetica (L.) as a Predominant Forage Species for Feeding of Goats
}

\author{
Khalil \\ Department of Animal Nutrition and Feed Technology, Faculty of Animal Science, \\ University of Andalas, Campus II Payakumbuh, West Sumatra, Indonesia
}

\begin{abstract}
The present study was aimed to define the suitability of Asystasia gangetica (L.) as a predominant forage for goats based on crude nutrient and mineral composition. Samples of forages collected by farmers were taken from 8 goat farms at three different sampling times. Fresh samples were taken from five different spots in each sample bunch from each farm, weighed and then sorted to determine the predominant species based on botanical composition and apparent frequency. Samples of six predominant species were chopped and mixed in with others from the same sampling time. Representative samples (about $150 \mathrm{~g}$ ) from each of the predominant species were dried and ground for chemical analysis. Botanical composition, apparent frequency, dry matter, nutrient content (crude protein, fiber and ash) and minerals ( $\mathrm{Ca}, \mathrm{P}, \mathrm{Fe}, \mathrm{Cu}, \mathrm{Mn}$ and $\mathrm{Zn}$ ) were measured. Results showed that of the 47 total kinds of vegetation fed to goats in the Payakumbuh region of Indonesia, the six predominant forage species included Axonopus compressus (23.4\%), Centrocema pubescens (6.8\%), $A$. gangetica (5.5\%), Panicum maximum (5.3\%) and Gliricidia sepium (5.2\%) and Manihot utilissima (5.0\%) foliage. The crude nutrient and mineral content of $A$. gangetica showed it to be a good source of protein and minerals, particularly $\mathrm{Ca}, \mathrm{P}, \mathrm{Cu}, \mathrm{Mn}$ and $\mathrm{Zn}$. It was concluded that $A$. gangetica could be used as a good complementary source of protein and minerals for goats.
\end{abstract}

Key words: Asystasia gangetica (L.), nutrient and mineral composition, predominant forages

\section{INTRODUCTION}

The Payakumbuh region of Indonesia which includes Payakumbuh city and 50 Kota districts in West Sumatra is a potential area for development of goat farming. This area is dominated by annual, small-scale crop estates as potential sources of fodder feed. Goat farms in this area are predominantly small-scale enterprises with an average flock size of 35.9 and 14.3 goats per farm for dairy and meat farms, respectively (Kurnia et al., 2015). Kurnia et al. (2015) reported that raising Peranakan-Etawah dairy goats has increased in popularity due to the potential market for goat milk and the high prices of bucks in Payakumbuh. Goats are mostly raised intensively with cut and carry feeding systems. Feed primarily consists of fresh wild vegetation, tree leaves and agricultural by-products. The wild vegetation forages are derived from diverse sources, like plantation areas, river banks, rice fields, idle lands, forest edges and roadsides and are comprised of various types of plants, such as native grass, legumes, broadleaf species and ferns. Even though these feeds often vary in nutrient and mineral and dry matter (DM) content (Khalil et al., 2015), mixtures of different plant species could be a good fodder feed for goats.

One the wild plant species found to be very palatable and often fed to goats in Payakumbuh is Asystasia gengetica, often called "akar jalar" or "aka jala" by locals. A. gangetica (Linn) T. Anderson belongs to the family of Acanthaceae and is commonly known as the Chinese violet. This rapidly growing herb spreads very quickly as a weed that infests crops, such as rubber, coffee and palm oil plantations in particular (Abdullah, 1985; Ong et al., 2008). It adapts well to low fertility soils and shaded areas (Ong et al., 2008; Samedani et al., 2013). Although this plant is considered a serious environmental and agricultural weed in Indonesia and Malaysia (Asbur et al., 2015), A. gangetica has some benefits. It contains various biologically active substances with various medicinal properties such as antiasthmatic, antidiabetic, anticancer and antioxidant, analgesic and anti-inflammatory, antimicrobial and antifungal effects (Akah et al., 2003; Ezike et al., 2008; Tilloo et al., 2012; Kanchanapoom and Ruchirwat, 2007; Hamid et al., 2011; Tilloo et al., 2012). A. gangetica is also known to have high nutritional value as an animal feed because it is rich in protein, fiber and favorable amounts of minerals (Yeoh and Wong, 1993; Odhav et al., 2007; Sobayo et al., 2012; Acipa et al., 2013; Adigun et al., 2014).

The dietary mineral intake of goats in Payakumbuh is almost entirely dependent on wild vegetation forages since mineral supplementation is an uncommon practice in this area. Minerals are an essential component of goat nutrition, with deficiencies being the primary cause of productivity loss. Despite comprising $4-5 \%$ of the body weight of animals, minerals levels are often a critical problem of goat nutrition. Minerals are of vital importance in various tissues for metabolic processes, maintenance of osmotic pressure, acid-base equilibrium and cellular permeability. They are also key components 
Pak. J. Nutr., 15 (9): 867-872, 2016

in the formation of hormones, enzymes and tissues such as bones (Underwood and Suttle, 1999). Ca, P, Mn, Cu, $\mathrm{Fe}$ and $\mathrm{Zn}$ are all minerals involved in governing the reproductive success of goats (Wilde, 2006). Cu and Zn directly affect reproductive events in sheep and goats, such as expression of estrus, embryo implantation and reduced spermatogenesis; indirectly, they affect overall animal health (Vazquez-Armijo et al., 2011). Thus, mineral deficiencies might lead to poor growth rates, reduced reproductive efficiency and decreased milk production. The present study aimed to define the suitability of $A$. gangetica as a predominant forage for goats in the Payakumbuh region of West Sumatra, Indonesia, based on its crude nutrient and mineral content. Determining crude nutrient and mineral contents of predominant plant forage species may be useful for improvement of feeding strategies for better growth, milk production and reproduction of goats. This data might also reflect the ability of farmers in the Payakumbuh area to explore the potential of various forage sources for their goats.

\section{MATERIALS AND METHODS}

Forages sample collection: The current study was initiated by field survey to define diversity and predominant forages for goats. Samples of forages collected by goat farmers were taken from 8 goat farms at three different times during the day. The average flock size was about 24 goats per farm. The farms were distributed throughout six different sub-districts of North Payakumbuh, West Payakumbuh, Lareh Sago Halaban, Luhak, Arau and Tanjung Aro. Fresh forage samples were taken from five separate spots within each forage bunch or sack directly after arriving at each farm in the afternoon. Plants were also identified with their local names.

Individual samples were placed in individual plastic bags, weighed and then sorted by species for calculation of botanical composition and apparent frequency. Latin and common names of samples were identified at the University of Andalas Biology Department, Padang, West Sumatra, Indonesia. The percent botanical composition was calculated by dividing the fresh weight of each plant species in each individual sample with the total weight of each individual sample. The percent apparent frequency of each species was calculated by dividing the apparent number of species in each individual sample with the total number of individual samples from each farm. The six most predominant species were then selected by ranking the forages based on botanical composition and apparent frequency.

Sample preparation and chemical analysis: The predominant species were manually chopped into pieces $(2-3 \mathrm{~cm})$ and then samples from the same species and sampling time were mixed, creating a total of 18 samples (6 predominant species, 3 sampling times).
Representative samples (about $150 \mathrm{~g}$ ) were dried in a forced draught oven at $60^{\circ} \mathrm{C}$ for $48 \mathrm{~h}$ and weighed again. Air-dried samples were ground through a 1-mm screen mill for analysis of crude ash, protein and fiber, DM and mineral ( $\mathrm{Ca}, \mathrm{P}, \mathrm{Fe}, \mathrm{Cu}, \mathrm{Mn}$ and $\mathrm{Zn}$ ) content.

$\mathrm{DM}$ and crude ash, protein and fiber were determined using the proximate analysis procedures described by the Association of Analytical Communities (2005). Samples for mineral analysis were prepared by wet digestion using concentrated sulfuric acid and hydrogen peroxide. The concentration of minerals was determined using an atomic absorption spectrophotometer (AAS, 1980). All results were reported on a DM basis.

Statistical analysis: Botanical composition and apparent frequencies of predominant forages were analyzed using simple descriptive statistics. Nutrient and mineral content of predominant forages were subjected to analysis of variance using a completely random design consisting of six predominant forage species and three replicates. Duncan's Multiple Range Test was applied to compare means. Differences were considered significant at $p<0.05$ (Steel et al., 1997).

\section{RESULTS AND DISCUSSION}

Diversity and predominance of forages: A wide variety of plant species are utilized as forages for goats in Payakumbuh. Table 1 shows a total of 47 plant species were recorded, consisting of 19 species of grasses (40.4\%), 11 species of broadleaves (23.4\%), 9 species of legumes (19.1\%) and 4 species each of fern (8.5\%) and tree leaves (8.5\%). Six plant species were identified to be predominant forages (51.2\% of total forages collected): Axonopus compressus (botanical composition: 23.4\%; frequency: 97.5), Centrocema pubescens (botanical composition: 6.8\%; frequency: 62.5), A. gangetica (botanical composition: 5.5\%; frequency: 45.0), Panicum maximum (botanical composition: 5.3\%; frequency: 37.5 ) and Gliricidia sepium (botanical composition: 5.2\%; frequency: 30.0) and Manihot utilissima (botanical composition: 5.0\%; frequency: 20.0) foliage.

Axonopus compressus was found to be the most important grass species for goats in Payakumbuh due to its high palatability and potential availability in the study sites. This shade-tolerant species is considered a weed and can be found in a wide variety of areas, like roadsides, river banks and crop plantations. The sub-districts of Lareh Sago Halaban, Harau, Mungka, Luhak, North and West Payakumbuh are dominated by annual, small-scale crop estates of cacao, coconut and banana. This kind of grass has become an integral part of crop plantations due to its positive effects on crop production by acting as a cover crop to suppress broadleaf weeds and soil erosion (Jurami, 2003; Samedani et al., 2013). 
Pak. J. Nutr., 15 (9): 867-872, 2016

Predominant legumes included $C$. pubescens and Pueraria phaseoloides, while Desmodium sp were predominantly $D$. ovalifilium and $D$. trifolium. Tree foliages consumed by goats in Payakumbuh included G. sepium (botanical composition: 30.0\%) and cassava leaves (botanical composition: 20.0\%; Table 1). G. sepium is commonly used as a live fence, while cassava root are widely used in snack foods.

Gangetica was the most predominant broadleaf plants recorded, followed by Amaranthus spinosus (botanical composition: $2.7 \%$ ), Borreria alata (botanical composition: $2.6 \%$ as well as Synderella vialis, Typhonium flagelliforme, Pteridium esculentum and Oxelis barrelia (botanical composition: 1.0-1.7\%). Farmers in the study sites also fed ferns to their goats. The main species known to be palatable were Lygodium flexuosum (botanical composition: $2.8 \%$ and Nephrolepis biserrata (botanical composition: 1.5\%; Table 1).

Crude nutrient and mineral composition of $A$. Gangetica compared to other predominant plants: Table 2 shows the proximate nutrient composition and mineral content of $A$. gangetica compared to the five other predominant plant species found in the study sites. Although crude protein content of $A$. gangetica (23.2\%) was lower than that of $G$. sepium (26.8\%) and cassava leaves $(25.3 \%)$, there was no significant difference ( $p>0.05$ ). G. sepium foliage included young leaves, stalks, seeds and flowers which have a high nutritional value (Handayanta et al., 2014). Ajayi et al. (2005) reported that G. sepium foliage was a good protein source for goats, containing $29.3 \%$ crude protein. The crude protein content of $A$. gangetica was significantly higher than that of the grasses Axonopus compressus (11.3\%) and $P$. maximum $(13.1 \% ; p<0.01)$ as well as legume $C$. pubescens $(17.2 \%$; $\mathrm{p}<0.05)$. While the crude protein content of Axonopus compressus and $P$. maximum were similar to that reported by Evitayani et al. (2004) in North Sumatra, Indonesia (10.6\% and $15.1 \%$, respectively), A. gangetica in the present study was slightly higher than that reported by Acipa et al. (2013) (18.9\%), Bindelle et al. (2007) (21.6\%) and Sobayo et al. (2012) (19.4\%).

The crude fiber content of $A$. gangetica (25.6\%) in the current study was lower than the grasses Axonopus compressus (35.3\%) and $P$. maximum (37.4\%) but higher than that reported by Sobayo et al. (2012) (15.5\%) and Bindelle et al. (2007) (21.6\%) in A. gangetica leaves. Considering its high protein and low fiber content, $A$. gangetica was found to be a good source of protein for goats in combination with native grasses.

In term of mineral composition, $A$. gangetica was found to be a good source of $\mathrm{Ca}(8.2 \mathrm{~g} / \mathrm{kg} \mathrm{DM})$ and $\mathrm{P}(11.3 \mathrm{~g} / \mathrm{kg}$ $\mathrm{DM})$. It contained significantly higher $\mathrm{Ca}$ than that of the grasses (Axonopus compressus: $2.1 \mathrm{~g} / \mathrm{kg}$ DM; $P$. maximum: $2.2 \mathrm{~g} / \mathrm{kg} \mathrm{DM}$ ) and the legume $C$. pubescens $(3.5 \mathrm{~g} / \mathrm{kg} \mathrm{DM})($ all $\mathrm{p}<0.05)$. The P content of $A$. gangetica was comparable to that of C. pubescens (12.6 g/kg DM) and cassava leaf (11.4 g/kg DM) (both $\mathrm{p}>0.05$; Table 2). The $\mathrm{Ca}$ and $\mathrm{P}$ content of $A$. gangetica in the present study were higher than that reported by Acipa et al. (2013) (Ca: $3.5 \mathrm{~g} / \mathrm{kg} \mathrm{DM}$; P: $7.9 \mathrm{~g} / \mathrm{kg}$ DM and Agea et al. (2014) (Ca: $5.0 \mathrm{~g} / \mathrm{kg}$ DM; P: $5.1 \mathrm{~g} / \mathrm{kg}$ DM). Furthermore, the Ca: $P$ ratio 1.5-2:1 of $A$. gangetica has nutritional importance. As a structural component, $\mathrm{Ca}$ combines with $\mathrm{P}$ to form the mineral portion of bone and teeth (Weaver and Heaney, 1999). However, because the $P$ concentration herein was higher than that of $\mathrm{Ca}, A$. gangetica should be mixed with G. sepium and/or cassava leaves, which contained the highest levels of $\mathrm{Ca}$ (20.1 and $15.0 \mathrm{~g} / \mathrm{kg} \mathrm{DM}$, respectively; Table 2).

A. gangetica was also found to be relatively rich in $\mathrm{Cu}$ (12.2 mg/kg DM), Mn (232.6 mg/kg DM) and Zn (60.6 g/kg DM), which showed comparable levels in Axonopus compressus and C. pubescens ( $p>0.05)$. In the current study, $A$. gangetica was found to be higher in $\mathrm{Mn}$ but lower in $\mathrm{Zn}$ and Cu compared to a report by Agea et al. (2014) (Mn: $106.3 \mathrm{mg} / \mathrm{kg}$ DM; Zn: $82.3 \mathrm{mg} / \mathrm{kg}$ DM; Cu: 37.2 $\mathrm{mg} / \mathrm{kg} \mathrm{DM})$. On the other hand, current results corresponded to $\mathrm{Cu}$ levels reported by Yeoh and Wong (1993) (9.0 mg/kg DM). Fe had the lowest concentration of all the minerals analyzed in $A$. gangetica $(89.3 \mathrm{mg} / \mathrm{kg}$ $\mathrm{DM} ; \mathrm{p}<0.05)$. Interestingly, previous studies have shown the Fe concentration of this plant vary greatly, from 138.7 $\mathrm{mg} / \mathrm{kg}$ DM (Acipa et al., 2013) to $43.7 \mathrm{mg} / \mathrm{kg}$ DM (Yeoh and Wong, 1993) and $183.4 \mathrm{mg} / \mathrm{kg}$ DM (Agea et al., 2014). Except for Fe, the native grasses Axonopus compressus and $P$. maximum were found to be relatively poor sources of $\mathrm{Ca}, \mathrm{P}, \mathrm{Mn}$ and $\mathrm{Zn}$ in the present study. These results correspond with earlier reports showing native forages were deficient in $\mathrm{Ca}, \mathrm{P}, \mathrm{Mg}$ and $\mathrm{Cu}$, which lead to an increased incidence of mineral deficiency in goats grazing in West Sumatra (Warly et al., 2006a,b). Low levels of Ca, $P, C u$ and $Z n$ in native grasses leading to their deficiency in grazing cattle has also been reported in South Sulawesi, Indonesia (Prabowo et al., 1991a,b).

Fodder leaves of cassava and $G$. sepium were found to be good sources of $\mathrm{Ca}$, possessing the highest content of all the predominant forages in the study sites $(15-20 \mathrm{~g} / \mathrm{kg}$ $\mathrm{DM})$. Cassava leaves also contained the highest Fe (308.4 mg/kg) and Zn (94.1 mg/kg DM) content. High concentrations of $\mathrm{Ca}$ and $\mathrm{Fe}$ in cassava leaves has also been reported by Fasuyi (2005). Furthermore, Adiwimarta et al. (2010) reported that cassava leaves were not only a good source of protein, but also had an anthelmintic effect in goats.

Overall, the total DM content of $A$. gangetica (14.6\%) was significantly lower than the grasses (23-24\%) and tree leaves (25-29\%) examined herein. The current DM content of this plant was comparable to that of $A$. gangetica leaf meal reported by Sobayo et al. (2012) and Odhav et al. (2007) (14.5 and 15.0\%, respectively), but higher than that reported by Bindelle et al. (2007) (10.5\%). Due to the 
Pak. J. Nutr., 15 (9): 867-872, 2016

Table 1: Forages for goats in Payakumbuh region of Indonesia

\begin{tabular}{|c|c|c|}
\hline Forage groups & Plant species (Botanical composition, \%) & Total No. of plants \\
\hline \multirow[t]{2}{*}{ Grasses } & $\begin{array}{l}\text { Axonopus compressus (23.4), Panicum maximum (5.3), Brachiaria decumbens (2.6), } \\
\text { Pennisetum pupureum (2.5), Paspalum conjugatum (2.3), Cynodon dactylon (2.0), } \\
\text { Chloris gayana (1.9), B. miliiformis (1.6), B. mutica (1.4), Setaria plicata (1.4), } \\
\text { Ottochloa nodosa (1.1), Imperata cylindrical (1.1), Cyperus rotundus (1.0), } \\
\text { C. plectostachyus (0.9), Eleusine indica (0.6), B. humidicola (0.3), } \\
\text { Chrysopogon acylatus (0.2), Digitaria ascendens (0.2) and } \\
\text { Ischaemum muticum (0.1) }\end{array}$ & 19 \\
\hline & Sub-total: $49.9 \%$ & \\
\hline \multirow[t]{2}{*}{ Broad leaves } & $\begin{array}{l}\text { Asystasia gangetica (5.5), Amaranthus spinosus (2.7), Borreria alata (2.6), } \\
\text { Synedrella vialis (1.7), Typhonium flagelliforme (1.6), Pteridium esculentum (1.1), } \\
\text { Oxelis barrelia (1.0), Cleome rutidosperma (0.4), Borreria laevis (0.4), } \\
\text { Dactyloctenium aegyptium (0.3) and Euphorbia hirta L. (0.3) }\end{array}$ & 11 \\
\hline & Sub-total: $17.6 \%$ & \\
\hline \multirow[t]{2}{*}{ Legumes } & $\begin{array}{l}\text { Centrosema pubescens (6.8), Pueraria phaseoloides (2.7), Mimosa pudica (1.7), } \\
\text { Desmodium triflorum (1.6), Desmodium ovalifolium (1.6), Arachis hypogaea } L(0.7), \\
\text { Macrophlium atropurpureum (0.3), Macarophlium axillare (0.3) and Vigna hateola (0.1) }\end{array}$ & 9 \\
\hline & Sub-total: $15.8 \%$ & \\
\hline Green leaves & $\begin{array}{l}\text { Gliricidia sepium (5.2), Manihot utilissima (5.0), Theobroma cacao (1.2) and } \\
\text { Artocarpus heterophyllus (0.1) }\end{array}$ & 4 \\
\hline \multirow[t]{3}{*}{ Fern } & $\begin{array}{l}\text { Lygodium flexuosum (2.7), Nephrolepis biserrata (1.5), Dicraopteris linearis (0.8) } \\
\text { and Stenochaena palustris }(0.2)\end{array}$ & 4 \\
\hline & Sub-total: $5.2 \%$ & \\
\hline & Total number of plants & 47 \\
\hline
\end{tabular}

Table 2: Crude nutrient, dry matter (DM) and mineral content of six predominant species of forages for goats in the Payakumbuh region of Indonesia

\begin{tabular}{|c|c|c|c|c|c|c|}
\hline & \multicolumn{6}{|c|}{ 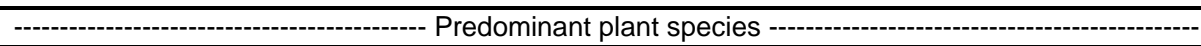 } \\
\hline & $\begin{array}{l}\text { Axonopus } \\
\text { compressus }\end{array}$ & $\begin{array}{l}\text { Centrosema } \\
\text { pubescens }\end{array}$ & $\begin{array}{l}\text { Asystasia } \\
\text { gangetica }\end{array}$ & $\begin{array}{l}\text { Panicum } \\
\text { maximum }\end{array}$ & $\begin{array}{l}\text { Gliricidia } \\
\text { sepium }\end{array}$ & $\begin{array}{l}\text { Manihot } \\
\text { utilissima }\end{array}$ \\
\hline \multicolumn{7}{|c|}{ Dominance parameters ( $\pm \mathrm{SEM}^{1}$ ) } \\
\hline Botanical composition, \% & $23.4 \pm 3.4$ & $6.8 \pm 2.4$ & $5.5 \pm 1.1$ & $5.3 \pm 1.3$ & $5.2 \pm 1.9$ & $5.0 \pm 2.6$ \\
\hline Apparent frequency, \% & $97.5 \pm 2.5$ & $62.5 \pm 15.3$ & $45.0 \pm 14.0$ & $37.5 \pm 16.7$ & $30.0 \pm 14.6$ & $20.0 \pm 12.5$ \\
\hline \multicolumn{7}{|c|}{ Crude nutrients (\% DM \pm SEM) } \\
\hline Crude protein ${ }^{2)}$ & $11.3 \pm 0.3^{\mathrm{c}}$ & $17.2 \pm 1.4^{\mathrm{b}}$ & $23.2 \pm 0.3^{\mathrm{a}}$ & $13.1 \pm 0.2^{\mathrm{c}}$ & $26.8 \pm 1.0^{\mathrm{a}}$ & $25.3 \pm 1.7^{\mathrm{a}}$ \\
\hline Crude fiber & $35.3 \pm 3.5^{\mathrm{a}}$ & $29.2 \pm 2.6^{\mathrm{ab}}$ & $25.6 \pm 3.2^{\mathrm{b}}$ & $37.4 \pm 1.9^{a}$ & $12.7 \pm 1.2^{\mathrm{c}}$ & $22.7 \pm 1.2^{\mathrm{b}}$ \\
\hline Crude ash & $10.4 \pm 0.4^{b}$ & $11.8 \pm 0.7^{b}$ & $12.7 \pm 0.3^{b}$ & $12.5 \pm 0.8^{b}$ & $8.0 \pm 0.2^{b}$ & $27.1 \pm 1.0^{\mathrm{a}}$ \\
\hline $\mathrm{DM}, \% \mathrm{FW}^{3)}$ & $23.9 \pm 0.2^{\mathrm{a}}$ & $17.1 \pm 0.2^{\mathrm{ab}}$ & $14.6 \pm 0.1^{\mathrm{b}}$ & $22.7 \pm 0.6^{\mathrm{a}}$ & $24.9 \pm 0.2^{\mathrm{a}}$ & $28.5 \pm 1.0^{\mathrm{a}}$ \\
\hline \multicolumn{7}{|l|}{ Minerals ( \pm SEM) } \\
\hline $\mathrm{Ca}, \mathrm{g} / \mathrm{kg} \mathrm{DM}$ & $2.1 \pm 0.3^{c}$ & $3.5 \pm 0.5^{c}$ & $8.2 \pm 1.7^{b}$ & $2.2 \pm 0.1^{c}$ & $20.1 \pm 1.9^{a}$ & $15.0 \pm 0.4^{\mathrm{a}}$ \\
\hline$P, g / k g ~ D M$ & $8.1 \pm 0.7^{\mathrm{ab}}$ & $12.6 \pm 0.5^{\mathrm{a}}$ & $11.3 \pm 2.4^{\mathrm{a}}$ & $5.8 \pm 1.1^{b}$ & $7.4 \pm 0.9^{\mathrm{ab}}$ & $11.4 \pm 0.9^{\mathrm{a}}$ \\
\hline $\mathrm{Fe}, \mathrm{mg} / \mathrm{kg} \mathrm{DM}$ & $243.2 \pm 49.2^{\mathrm{a}}$ & $309.3 \pm 15.1^{a}$ & $89.3 \pm 4.9^{b}$ & $196.6 \pm 16.5^{a}$ & $166.3 \pm 7.6^{\mathrm{ab}}$ & $308.4 \pm 0.6^{a}$ \\
\hline $\mathrm{Cu}, \mathrm{mg} / \mathrm{kg} \mathrm{DM}$ & $10.3 \pm 2.3^{\mathrm{ab}}$ & $17.3 \pm 1.7^{\mathrm{a}}$ & $12.2 \pm 3.2^{\mathrm{ab}}$ & $9.4 \pm 0.7^{\mathrm{ab}}$ & $3.9 \pm 0.6^{c}$ & $7.1 \pm 0.5^{\mathrm{ab}}$ \\
\hline $\mathrm{Mn}, \mathrm{mg} / \mathrm{kgDM}$ & $178.5 \pm 7.3^{b}$ & $164.3 \pm 7.3^{b}$ & $232.6 \pm 12.0^{b}$ & $73.0 \pm 4.1^{\mathrm{c}}$ & $179.7 \pm 22.0^{b}$ & $374.6 \pm 16.2^{\mathrm{a}}$ \\
\hline $\mathrm{Zn}, \mathrm{mg} / \mathrm{kg} \mathrm{DM}$ & $41.7 \pm 1.6^{\mathrm{b}}$ & $99.5 \pm 21.6^{a}$ & $60.6 \pm 2.8^{\mathrm{ab}}$ & $48.1 \pm 2.4^{b}$ & $42.4 \pm 4.5^{\mathrm{b}}$ & $94.1 \pm 10.2^{\mathrm{a}}$ \\
\hline
\end{tabular}

${ }^{1)}$ SEM: standard error of the mean. ${ }^{2) a b c}$ Means within same row with different superscripts are significantly different $(p<0.05) .{ }^{3)} \mathrm{FW}:$ Fresh weigh

relatively low total DM content of this plant, it is therefore necessary to combine $A$. gangetica with $G$. sepium and cassava leaves in order to ensure that goats fed under confinement ingest the quantity of fresh forages required to meet nutrient and DM needs. As shown in Table 2, the leaves of $G$. sepium and cassava contained the highest total DM (24.5 and $28.5 \%$, respectively; $p<0.05)$. Cassava leaves were offered to goats in wilted form by sun drying to minimize negative toxic effects. Feeding a variety of preferred plants available to goats would ensure adequate DM and nutrient intake from the forage and help to overcome low DM intake, a constraint to the use of browse plants in small ruminant feeding.

In general, even though grasses accounted for the majority plant forages in the study sites, had lower crude protein and minerals but higher crude fiber content, combining them with other predominant plant species, including $A$. gangetica, $C$. pusbescens and foliages high in crude protein and minerals, make them good forages. Furthermore, feeding of $A$. gangetica and fodder from cassava and tree leaves to goats should be increased due to their high nutritional content. Because of relatively good 
fodder feeds, the average milk production has been reported to be about $0.8 \mathrm{~L} / \mathrm{head} / \mathrm{d}$ in Payakumbuh by Kurnia et al. (2015) and 0.5-0.9 L/d by Novita et al. (2006). Current findings also show that farmers in the Payakumbuh area of Indonesia were able to explore the potential of various forage sources for their goats.

Conclusions: Of the 47 total kinds of vegetation fed to goats in Payakumbuh, the six predominant forages included Axonopus compressus (23.4\%), C. pubescens (6.8\%), A. gangetica (5.5\%), P. maximum (5.3\%) and foliage of G. sepium (5.2\%) and Manihot utilissima (5.0\%). Levels of crude protein and $\mathrm{Ca}$ in $A$. gangetica were significantly higher than the grasses, but lower than in $G$. sepium and cassava leaves. The crude nutrient and mineral content of the $A$. gangetica shows it is a good source of protein, $\mathrm{Ca}, \mathrm{P}, \mathrm{Mn}, \mathrm{Zn}$ and $\mathrm{Cu}$. Thus, it was concluded that $A$. gangetica could be used as a good complementary source of foliage protein and minerals for goats.

\section{ACKNOWLEDGEMENTS}

The author greatly appreciates Bioscience Editing Solutions (www.Biosienceeditingsolutions.com) of United States of America for language editing services.

\section{REFERENCES}

AAS, 1980. Analytical methods for atomic-absorption spectrophotometry. Perkin-Elmer Corporation, Norwalk, Connecticut, USA.

Abdullah, R., 1985. Bological control of Asystasia by sheep grazing. Planters' Bull., 183: 43-49.

Acipa, A., M.K. Mugisha and H.O. Origa, 2013. Nutritional profile of some selected food plants of Otwal and Ngai sub counties, Oyam district, Northern Uganda. Afr. J. Food, Agric., Nutr. Dev.,13: 7428-7451.

Adigun, O.S., E.N. Okeke, O.J. Makinde and M.O. Umunna, 2014. Effect of replacing wheat offal with Asystasia gangetica leaf meal (ALM) on growth performance and haematological parameters of weaner rabbits. Greener J. Agric. Sci., 4: 009-014.

Adiwimarta, K., J. Daryatmo, E.R. Orskov, R.W. Mayes and $\mathrm{H}$. Hartadi, 2010. Utilization of cassava leaf and carica papaya leaf as feed and anthelmintics for goats. Adv. Anim. Biosci., 1: 114-114.

Agea, G.J., J.M. Kimondo, D.A. Woiso, B.B. Obaa, P. Isubikalu, J.B.L. Okullo, J. Obua, J. Hall and Z. Teklehaimanot, 2014. Nutritionally essential macro and micro minerals contents of fifteen selected leafy wild and semi-wild food plants (WSWFPs) from Bunyoro-Kitara Kingdom, Uganda. J. Nat. Prod. Plant Resourc., 4: 35-42.

Ajayi, D.A., J.A. Adeneye and F.T. Ajayi, 2005. Intake and nutrient utilization of West African Dwarf goats fed mango, Fescues and gliricidia foliages and concentrates as supplement to a basal diet of guinea grass. W. J. Agric. Sci., 1: 184-189.
Akah, P.A., A.C. Ezike, S.V. Nwafor, C.O. Okoli and N.M. Enwerem, 2003. Evaluation of the anti-asthmatic property of Asystasia gangetica leaf extracts. J. Ethnopharmacol., 89: 25-36.

Association of Analytical Communities, 2005. Official Methods of Analysis of AOAC International. 18th ed. Assoc. Off. Anal. Chem. Arlington.

Asbur, Y., S. Yahyar, K. Murtilaksono, Sudradjat and E.S. Sutarta, 2015. Study of Asystasia gangetica (L.) Anderson utilization as cover crop under mature oil palm with different ages. Int. J. Sci. Basic Appl. Res. (IJSBAR), 19: 137-148.

Bindelle, J., Y. Ilunga, M. Delacollette, M.M. Kayij, J.U. M'Balu, E. Kindele and A. Buldgen, 2007. Voluntary intake, chemical composition and in vitro digestibility of fresh forages fed to guinea pigs in periurban rearing systems of Kinshasa (Democratic Republic of Congo). Trop. Anim. Health Prod., 39: 419-426.

Evitayani, L. Warly, A. Fariani, T. Ichinohe and T. Fujihara, 2004. Study on nutritive value of tropical forages in North Sumatra, Indonesia. Asian-Aust. J. Anim. Sci., 17: 1518-1523.

Ezike, A.C., P.A. Akah and C.O. Okoli, 2008. Bronchospasmolytic activity of the extract and fractions of Asystasia gangetica leaves. Int. J. Appl. Res. Nat. Prod., 1: 8-12.

Fasuyi, A.O., 2005. Nutrient composition and processing effect of cassava leaf (Manihot esculenta, Crantz) antinutrients. Pak. J. Nutr., 4: 37-42.

Hamid, A.A., O.O. Aiyelaagbe, R.N. Ahmed, L.A. Usman and S.A. Adebayo, 2011. Preliminary phytochemistry, antibacterial and antifungal properties of extracts of Asystasia gangetica Linn T. Anderson grown in Nigeria. Adv. Appl. Sci. Res., 2: 219-226.

Handayanta, E., S. Ifar and Hartutik and Kusmartono, 2014. Botanical composition and quality of ruminant feed resources in the dry land farming areas in Yogyakarta, Indonesia. J. Biol. Agric. Healthcare, 4: 26-33.

Jurami, A.S., 2003. Turf grass: types, uses and maintenance, Garden Asia, 8: 40-43.

Kanchanapoom, T. and S. Ruchirwat, 2007. Megastigmane glucoside from Asystasia gangetica (L.). J. Nat. Med., 61: 430-433.

Khalil, M.N. Lestari, P. Sardilla and Hermon, 2015. The use of local mineral formulas as a feed block supplement for beef cattle fed on wild forages. Media Peternakan, 38: 34-41.

Kurnia, Y.F., Ferawati, Reswati and Khalil, 2015. Prospect of dairy goat production for small-scale enterprises in Payakumbuh West Sumatra. Pak. J. Nutr., 14: 141145.

Novita, C.I., A. Sudono, I.K. Sutama and T. Toharmat, 2006. Produktivitas kambing Peranakan Etawah yang diberi ransum berbasis jerami padi fermentasi. Media Peternakan, 29: 96-106. 
Odhav, B., S. Beekrum, U. Akula and H. Baijnath, 2007. Preliminary assessment of nutritional value of traditional leafy vegetables in Kwa Zulu-Natal. South Afr. J. Food Comp. Anal., 20: 430-435.

Ong, K.H., M.T. Lim, P. Priscilla and C.J. Keen, 2008. Ground vegetation response to fertilization in an Azadirachta excelsa stand in Johore, Malaysia. J. Agronomy, 7: 327-331.

Prabowo, A., L.R. McDowell, N.S. Wilkinson, C.J. Wilcox and J.H. Conrad, 1991a. Mineral status of grazing cattle in South Sulawesi, Indonesia. 1. Macro minerals. AJAS, 4: 11-120.

Prabowo, A., L.R. McDowell, N.S. Wilkinson, C.J. Wilcox and J.H. Conrad, 1991b. Mineral status of grazing cattle in South Sulawesi, Indonesia. 2. Micro minerals. AJAS, 4: 121-130.

Samedani, B., A.S. Juraimi, M.P. Anwar, M.Y. Rafii, S.H. Sheikh Awadz and A.R. Anuar, 2013. Competitive interaction of Axonopus compressus and Asystasia gangetica under contrasting sunlight intensity. The Scientific World J., 1: 1-8.

Sobayo, R.A., O.A. Adeyemi, O.G. Sodipe, A.O. Oso, A.O. Fafiolu, I.M. Ogunade, O.S. Iyasere and L.A. Omoniyi, 2012. Growth response of broiler birds fed Asystasia gangetica leaf meal in hot humid environment. J. Agric. Sci. Env., 12: 53-59.

Steel, R.G.D., J.H. Torrie and J.H. Dicky, 1997. Principles and Procedures of Statistics: A Biometritrical Approach. 3rd Ed. McGraw-Hill Book Co. Inc., New York, USA.
Tilloo, S.K., V.B. Pande, T.M. Rasala and V.V. Kale, 2012. Asystasia gangetica: Review on multipotential application. Int. Res. J. Pharmacy, 3: 18-20.

Underwood, E. and N.F. Suttle, 1999. The Mineral Nutrition of Livestock. Commonwealth Agricultural Bureux. London.

Vazquez-Armijo, J.F., L. Rojo, A.Z.M. Salem, D. Lopez, J.L. Tinoco, A. Gonzalez, N. Pescador and I.A. Dominguez-Vara, 2011. Trace elements in sheep and goats reproduction: a review. Tropical and Subtropical Agroecosystems, 14: 1-13.

Warly, L.A. Fariani, Evitayani, M. Hayashida and T. Fujihara, 2006a. Mineral status of forages and grazing goats in West Sumatra, Indonesia: 1. Macro minerals. J. Food, Agric. Environ., 4: 234-236.

Warly, L.A. Fariani, Evitayani, M. Hayashida and T. Fujihara, 2006b. Mineral status of forages and grazing goats in West Sumatra, Indonesia: 2. Micro minerals. J. Food, Agric. Environ., 4: 204-207.

Weaver, C.M. and R.P. Heaney, 1999. Calcium. In: Modern Nutrition and Disease, M. E. Shils, J.A. Olson, M. Shike and A.C. Ross (Ed.), Williams and Wilkins, Baltimore M.D., USA, pp: 141-155.

Wilde, D., 2006. Influence of macro and micro minerals in the peri-parturient period on fertility in dairy cattle. Anim. Reprod. Sci., 96: 240-249.

Yeoh, H.H. and P.F.M. Wong, 1993. Food value of lesser utilised tropical plants. Food Chem., 46: 239-241. 